\title{
Appraising the Effect of Boko Haram Insurgency on the Agricultural Sector of Nigerian Business Environment
}

\author{
S.A Adebisi, O.O Azeez and R Oyedeji \\ University of Lagos, Nigeria
}

\begin{abstract}
The study is an appraisal of Boko Haram's insurgency on the agricultural sector of the Nigerian business environment. A time series analysis research method was adopted, while descriptive statistics and t-test were used to analyse the secondary data before and during the insurgency. The result of the findings showed that agricultural valued added to the GDP was high before Boko Haram disruption and has reduced during the period of insurgency. Based on the findings, the study recommends that Government should take legal and justifiable action to ensure that the ills caused by Boko Haram to the agricultural sector are arrested and farmers encouraged with better incentives to go back to farm.
\end{abstract}

\section{Keywords}

Boko Haram, Agriculture, Government, Business and Environment

\section{Introduction}

Agriculture in Nigeria is the most important sector of the economy from the standpoint of rural employment, sufficiency in food and fibre, and export earning prior to the discovery of oil (Towobola, et.al 2014). The above assertion is based on the fact that as at independence in 1960, little was known of petroleum as a source of revenue for the Nigerian economy. There was sustained emphasis on agriculture such that Nigeria was a major exporter of agricultural products like palm produce, cocoa, groundnut, cotton and rubber. In addition to these cash crops, the national agricultural system produced enough food crops such as yam, cassava, maize, millet, sorghum and soya beans so that there was practically no need for food importation. Hitherto, agriculture accounted for over $60 \%$ of the nation's Gross Domestic Product (GDP) (Francis and David, 2012).

According to Akinwumi (2014), in the 1960s, before the discovery of oil, Nigeria was known to be a major agricultural producer in the world. Between 1962 and 1968, export crops were the country's main foreign exchange earner. Nigeria was number one amongst other countries like Malaysia and Indonesia in products like palm oil and groundnuts, even ahead of the US and Argentina. Nigeria's status with $47 \%$ in these products which made her as an agricultural centre has declined steeply. While Nigeria once provided $18 \%$ of the world demand of cocoa, second in the world in the $1960 \mathrm{~s}$, that figure has drastically reduced to $8 \%$. Also the country which was known to produce $65 \%$ of

Copyright (C) 2016 Victoria. This document has been published as part of the Journal of Law and Governance in both online and print formats. Educational and non-profit institutions are granted a non-exclusive licence to utilise this document in whole or in part for personal or classroom use without fee, provided that correct attribution and citation are made and this copyright statement is reproduced. Any other usage is prohibited without the express permission of the publisher. tomatoes in West Africa has become the leading importer of tomato paste. Despite the poor performance of the agricultural sector which is below economic expectation, the sector is still capable of aiding socioeconomic development of people living in rural areas, most especially in the northern states as they engaged more in agriculture in order to sustain themselves, and traded within their 
capacity or capabilities for profit. However, the on-going Boko Haram insurgency has affected the rural agricultural economy the northern, part of Nigeria, hence, this work is an appraisal of the impact of Boko Haram insurgency on the agricultural sector of the Nigerian business environment.

\section{Statement of Problem}

Reduction in the production of agricultural outputs in Nigeria began with the discovery of crude oil in 1956 while commercial exploitation commenced in the early ' $70 \mathrm{~s}$. The discovery of oil in Nigeria which was supposed to be a blessing and an additional source of income to the country has become a means of distorting our economy. Kathleen (2014) observed that Agricultural products which were the main exports and major source of foreign exchange earnings for the country declined suddenly. In the same vein, Lawal (2012) noted that many government policies have been enacted to develop the sector but these have not achieved much. This situation is further worsened by the advent of Boko Haram (a sect of violent people). Boko Haram which means "denouncing western education" has led to the displacement of farmers in Northwest and Northeast of Nigeria. This insurgency has made many farmers relocate to other places where there is peace in other to save their lives, causing them to leave their farmlands behind as it is not mobile as highlighted by (Mustapha, 2015).

According to Lawal (2012), agriculture is not limited to crop production alone. The Northerners also involve in animal husbandry and they were engaged in business even before the colonial era. The manifestation of Boko Haram recently has been a great threat to the Nigeria business environment as farming and other business activities are being harmed (Council on Foreign Relations, 2015). Nomadic cattle rearers who have been taking their cattle out for grazing have abandoned their business, as the environment is no longer safe for them. The lives of those that are still involved in the business are also at stake, because an attack of Boko Haram can occur at any moment. This has led to decreases in milk production, meat production and by extension an increase in the price of the cattle. Poultry farmers also do not find their business lucrative anymore, as the people purchasing the goods have been displaced.

Some of the crops they produced are also perishable and need to be consumed on time. Consequently, this has also led to poor transportation, high transport cost, displacement of properties and high risk to lives. These crops get spoiled leading to wastages. Also some of these crops need to be marketed on time but due to imposed curfew and several restriction of movement; they perished and become unmarketable (Mustapha, 2015).

The hazard caused by Boko Haram is not only felt in Nigeria but in some other parts of the Africa. Cameroon, a country sharing border with Nigeria in the North East part is also affected. Traders from this country can no longer come to Maiduguri (Nigeria) to buy or sell. The border was closed some time ago, restricting importation or exportation from the countries which affected their economy. The Niger Republic economy is also affected, as she shares border with Nigeria and both countries practise goods exchange with one another.

Akinwumi (2014) revealed that climate favours the Nigeria agriculture business environment and the country needs World Bank assistance to boost the sector. Dabugat (2013) identified that the present problem of low agricultural productivity is due to violence in the Northern States. This forms the basis of arguments of this paper which examines the effect of Boko Haram on the agricultural sector of the business environment of Nigeria.

\section{Objective}

This paper is aimed at investigating the impact of Boko Haram insurgency on the agricultural output with respect to Gross Domestic Product (GDP) in Nigeria within the period under investigation.

\section{Hypothesis}


(Ho) Boko Haram insurgency has no significant effect on the Agricultural Sector of Nigerian Business Environment: Percentage of output to GDP from 1994 to 2003 and percentage of output from 2004 to 2013.

(Hi) Boko Haram insurgency has significant effects on the Agricultural Sector of Nigerian Business Environment: Percentage of output to GDP from 1994 to 2003 and percentage of output from 2004 to 2013.

\section{Literature Review}

\section{An Overview of the Nigerian Agricultural Economy}

Agriculture is the cultivation of land, raising and rearing of animals for the purpose of production of food for man, animals and raw materials for industries. It involves and comprises crop production, livestock, forestry, and fishery, processing and marketing of these agricultural products (Mabuza et al, 2008). In the early 1950's to 1960's agriculture played a vital role in stimulating economic growth and development in Nigeria. It provided employment to millions of Nigerians and over seventy percent $(70 \%)$ of the labour force which are mostly from rural areas were employed in agriculture (Abayomi, 2006). In the same period, agriculture contributed over $70 \%$ to the country's export earnings (CBN, 2007). Indeed agriculture provided the main stimuli to the Nigerian economic growth despite the small farm holding and primitive systems. The contribution of agriculture dominated other sectors' contribution to the GDP.

Usman (2006) reported that Nigeria has about 140 million people of which about $70 \%$ are engaged in agricultural production and this provides subsistence for two-thirds (2/3) of Nigerians who are low income earners, while the Northern part can guarantee the production of cereals such as sorghum, maize, millet, groundnut, cowpea and cotton, the Middle Belt and the South have the potential to produce tubers such as cassava, yam, cocoyam and other crops like plantain as well as maize (Abdullahi, 2003). In addition to crops, the country is also involved in the production of livestock, fisheries, forestry and wildlife. Ukpong and Iniodu (1995) also supported the view that Nigeria is generally endowed with abundant natural resources, numerous perennial sources of water and a favourable tropical climate. Rainfall is generally adequate and fairly well distributed throughout the country. Out of the 98.321 million hectares of land available in Nigeria, about $75.30 \%$ may be regarded as arable land, $10 \%$ is under forest reserves and the remaining $14.70 \%$ is assumed to be made up of permanent pastures, built up areas and uncultivable waste (Olajide, 1980). Igboeli, (2000), noted that agriculture is still a major sector and remains the cornerstone of the Nigerian economy. In the pre-and post-independence era (1930 to 1965), the Nigerian economy was predicated on agriculture. Agriculture employed about $70 \%$ to $80 \%$ of the country's labour force (CBN, 1995), and contributed $60 \%$ of the nation's gross domestic product (GDP) and foreign exchange earnings (Ugwu and Kanu, 2012).

\section{The support of Government towards the development of the Agricultural Sector}

The government of Nigeria usually allocate some amount of money to the agricultural development yearly (Lawal, 2011). Although these allocations have not been in linear progression method due to political instability, some agricultural policies have served as back-up so as to boost output which has a multiplier effect on Gross Domestic Product (GDP) and the standard of living of its populace (Ogen, 2007). Agriculture was the major source of employment, foreign income, and has been feeding about $70 \%$ of the citizens in pre and about 10 years post-independence. The discovery of oil led to the neglect of the sector in the 1970s and a shortfall of its contribution towards GDP. The government then reacted quickly by establishing the Nigeria Agricultural and Cooperative Bank (NACB) in 1973. The bank's main function was to provide loans to farmers in order to increase production in areas like fisheries, cattle rearing, poultry, piggery, land cultivation and planning, timber production, horticulture and the likes. It also includes storage and processing, distribution and marketing (Lawal, 
2011). As part of government interest in agriculture, the capital base of the bank was increased from \$2.0million to $\$ 10.0$ million. This was done to encourage new farms and protect existing agricultural businesses seeking agricultural loan. The establishment of Agricultural Development Projects in 1975 were to provide assistance to farmers in their different locations. The introduction of Operation Feed the Nation (OFN) was good news to everybody which helped to heal and improve agriculture especially in small scale levels (Iwuchukwu and Igbokwe 2012).

Agriculture represents a veritable vehicle for social economic development of the country by which the government provided financial incentives and promoted, encouraged and supported the growth and development of agriculture through the establishment of The Agricultural Credit Guarantee Scheme (ACGS) Fund in 1977 which commenced operation in 1978. The fund was meant to provide loans to farmers (individual, cooperative society and limited liability company) beginning from \$5000 to $\$ 10$ million with or without collateral depending on the amount. This was done through commercial and merchant Banks by the Central Bank of Nigeria (Lawal, 2011 and Evbuomwan, et al., 2003). More to the list is the establishment of Rural Banking Programme launched in 1977 and the River Basin Development Authority in 1977.

Daniel and Ihechituru, (2012) and Olugboyega and Kolawole, (2012), posited that Governments over the world recognised the importance of agriculture, because it creates employments, foreign exchange and helps to feed the growing population and Nigeria is not an exception. Nigeria government has hitherto helped to start and grow agriculture business through the establishment of the Green Revolution Programme launched between 1980 -1983. This was meant to make Nigeria self-sufficient in food designed for five years. The Directorate for Foods Roads and Rural Infrastructure (DFRRI) scheme was launched in 1986. Nseabasi (2012) opined that the aim was to ease the storage, distribution and marketing of farm products through the creation of good roads and other infrastructures for rural dwellers who are mostly farmers. The establishment of Federal universities of agriculture in some part of the country was also to encourage students and youths to develop interest in agriculture.

According to Okogun and Abang (2012), the Nigeria Insurance Scheme established in 1987 by the federal government was to protect farmers and also reduce their loss arising from natural disaster. The government continued its effort by establishing the Nigeria Agricultural Land Development Authority (NALDA). This policy was imbibed at State and Local government levels. The objective was to make farmers have access to large farm land without stress. Successive government in Nigeria have initiated numerous programme and policies to generate employment, reduce poverty and improve the growth of the economy through agriculture by supplying farmers with fertilizer and distributing it at subsidized prices, low interest rate on loan to farmers, and $100 \%$ tax reliefs on farm products. As observed by Nwachuwku and Ezeh (2007), the Strategic Grains Reserve Authority (SGRA), the Accelerated Crop Production (ACP) and the Better Life Programme for Rural Dwellers which was replaced by Family Support Programme (FSP), and was gender specific (rural women) were all established to improve the productive capacities of peasant farmers as well as improving their incomes and well-being. The Nomadic Education was to encourage mobile farming while schooling. In a nut shell all these programmes were geared towards a well sustained economic growth and by extension its development. 


\section{The Effect of Boko Haram Insurgency on the Nigerian Agricultural Sector}

Terrorism is becoming a global phenomenon. The world is becoming an evil jungle. The killing of people and destruction of properties are seen as an everyday affair and gradually becoming a way of life. The safety of lives and properties are no more guaranteed. Terrorist attack is in the news on a daily basis and the intensity of religious terrorism is increasing every day (Council on Foreign Relations, 2011). The number of death from terrorism is increasing on yearly basis and the world death toll in 2013, increased by $61 \%$ when compared to 2012. And about 10,000 attacks in 2013. It has been observed that the $21^{\text {st }}$ century terrorism is done through religious ideology supported by some Islamic groups called Al-Qaeda, Islamic State, Boko Haram and the Taliban. These groups are Islamic militant that do irrational bombing and suicide killing of innocent people. The worst terrorist attack ever noticed in the $21^{\text {st }}$ century was September 11, 2001 attacked on the World Trade Centre in New York which killed about 3,000 people, the terrorist attack on India Parliament in December 13, 2001 and the July 7, 2005 attack in London city. These attacks are in connection with Al-Qaeda militant group. The violent gun shot in a shopping mall in Kenya in 2013 and the recent killings of innocent university students in the country have made the world very unsafe to live. The persistent attack by Islamic sect called Boko Haram in Nigeria and some of the neighbouring countries are unbearable. These groups attack on different countries is a fight against Western culture and education (Olaide, 2013).

There has been a general notion by some Islamic extremists that Western education is bad and must be eradicated. This has been followed by terrorism in different countries aimed at destabilizing the peace of the world and making living together in harmony without discriminating against any other forms of worship. Religious violence and terrorism are increasing and becoming a threat to the world business environment. These notorious groups are violent Muslim extremists who interpret religious ideologies to suit self-desires. The $21^{\text {st }}$ century religious terrorist group such as Al-Qaeda, Taliban, Boko Haram etc justify their actions on Islamic principles. They believed that violence is the only means to fight an existing government and to cause change.

Literature has adduced that terrorism in Nigeria and some other countries in Africa is caused by porous borders, poverty, weak security, inconsistent government policies and disagreement among Muslim scholars. The Boko Haram group in Nigeria and neighbourhoods and the Al-Shabaab in Kenya are enough to discourage Westerners from doing business with Africa. More than 1.5 million people, mostly farmers, have been forced to flee their homes as Boko Haram intensified its insurgency in the past years according to the United Nations High Commissioner for Refugees. The worst-hit states of Borno, Yobe and Adamawa produce staple foods such as cowpeas, rice, millet, sorghum, corn and yams as well as tomatoes, onions, fish and livestock for both local consumption and export markets.

Maiduguri, the capital of Borno state in Nigeria has been deserted by both indigenes and foreigners, as the people there have been jobless. The movement of these people is under restriction due to the curfew imposed by the government or the Boko Haram activities. This violent set of people have bombed bridges, communication gadgets and other social amenities which are necessary for habitation linking Nigeria with neighbouring countries in the north eastern part of Nigeria. Some bridges linking villages where major famers dwell in Yobe State have been blown up. Fish farmers in Yobe State are unable to transport their products to the South. Instead of forty trucks per week, only a maximum of seven trucks of fish products can be transported to South thereby causing increase in prices. The fear of the notorious group has stopped farmers from going to farm even when the climatic condition is very favourable and could have led to a bountiful harvest. The attacks on villagers, burning down homes and indiscriminating shooting have forced survivors to relocate to the South especially in Borno State (Sahara Reporters, 2015).

The government has also been spending a lot to cater for refugees. The situation has led to an increase in government expenditure. Boko Haram has brought pain and death to Nigerian business especially in the agricultural sector of the nation. The aftermath of Boko Haram is hunger as it has displaced 
farmers from their settlements and buyers into untold hardship. Each attack in Borno, Yobe or Adamawa States kills human beings and destroys farm products. The Boko Haram insurgency which started in 2002 lunched its full-scale attack in 2009 and since then became more violent each day. The hot zones are Borno, Yobe and Adamawa States which have the largest farm land in the country dominated by different kinds of farmers. These States produce stable foods such as corn, cowpeas, rice, millet, tomatoes, yams, onion, fish and livestock. The fear of Boko Haram has prevented farmers from cultivating their farm land and the few that did have lost their farm products to the terrorists who set them ablaze, killing the farmers and destroying their products. These States are closer to Niger, Chad and Cameroon where agricultural business activities were booming especially in area of export of groundnuts and groundnut oil (Mustapha, 2015). These activities are now becoming history due to Boko Haram attacks. The government must use all means to fight these terrorist to allow farmers go back to business in order to boost the Gross Domestic Product (GDP) of the country.

Moreover, agriculture's decline as a share of GDP has more implications in the Northern States, where it is a source of livelihood. With the influence of Boko Haram, the share of people engaged in subsistence agriculture will continue to reduce if nothing is done to arrest the situation. Although GDP can depend on macroeconomic activities, agriculture in Nigeria is also a major source of GDP and therefore cannot be left to be destroyed by a violent sect called Boko Haram. The main thing that will reduce poverty and create employment in Nigeria is agriculture. Agriculture in Nigeria is beyond food for man and animals. It is a source of income to the country through exportation and raw materials for industries in the country. The importance of agriculture in the creation of employment, industrialization and poverty reduction cannot be over emphasized.

In summary, the contribution to government revenue has been decreasing since independence due to the oil boom, political instability and lack of continuity in government policies coupled with corruption. The recent reoccurrence of Boko Haram is very devastating to the Nigeria business. The contribution of agriculture to Gross Domestic Product (GDP) has reduced drastically due to the discovery of oil and neglect of the agricultural sector, and to worsen the situation is the displacement and death of farmers', their products and their marketers. Business strives only in stable environment. Boko Haram has made agriculture business environment in the Northern States of Nigeria very turbulent. The factors of production which are land, labour, capital and entrepreneurdhip are not stable. The bombing of farm products and lands destroys both the future outputs and makes the lands not viable for the next farming season. The killing of youth and also using them for violence complicates the situation. The male youths who are more active with much strength and can be a good source of labour are people the Boko Haram is using for attacks. Capital is the amount invested in the business. Capital can only be invested when the risk associated with it can be controlled or minimised. No farmer will want to invest in a business where the risk in the business environment is very high. Entrepreneurs are the owners of the business. They have to run for safety and divert to another business in a peaceful environment

No nation can afford to treat with levity the security of its territorial region and of its people. Indeed every aspect of human endeavour, be it health, environmental, food, economy, political, social, education, sport and physiological etc, stands to be greatly affected by the state of security or insecurity of that nation. It is no longer news that in recent time, Nigeria has been burdened with challenging security issues chief among which is the Boko Haram insurgency (Adebayo, 2014). According to Abidde (2014), Boko Haram made its presence known in 2004, in Yobe State and by 2011 it made its presence known to the global community by bombing the United Nations headquarters in Abuja. Especially in the last two years, it has wilfully attacked hundreds of buildings and killed many innocent Nigerians. Until recently, the Nigerian security and intelligence agencies knew very little about the group's origin and philosophy, its raison d'être, and its goals and end game (Abidde, 2014). In the past, Boko Haram insurgents have used Cameroon as a safe haven for initiating hit-and-run attacks on neighbouring Nigerian territory. The Nigerian government responded by deploying a military presence on the northern border. Further attempts to prevent the sect extremists from accessing targets across the porous boundary have culminated in official closure of the Cameroon border (Merrick and Li, 2014). 
The North wields $78 \%$ of Nigeria's land which supports most of Nigeria's agriculture (food, cash crops and livestock) (Innocent, 2012). With increased intensity of bombings in the north, there was strategic mass movement of individuals from the most affected northern states especially in early 2012. This was accentuated by the uncertainties surrounding the fuel price crisis at the time. The movements were of a strange kind since both Southerners and Northerners simultaneously moved from Boko Haram strongholds. While the affected areas of North move to the South-East in hundreds, others relocated to the South-West (Innocent, 2012).

According to Merrick and Li (2014), the sect has inflicted violence in northern Nigeria for the past five years. Boko Haram means "western education is forbidden." It upholds its principles by targeting schools, Christian churches, and more recently, the entire towns. Since 2009, Boko Haram insurgency is believed to have killed thousands of people and destroyed properties valued at over a billion dollars. This includes government buildings, livestock and produce. The insurgents continue to torch public buildings and steal large quantities of produce, thereby destroying livelihoods of farmers and forcing hundreds of businesses to close or relocate. With Boko Haram's northern insurgency concentrating where agricultural activity is highest, Nigeria's national government is becoming increasingly concerned with threats to food security (Merrick and Li, 2014). Either way one looks at the group, its activities have been very damaging both physically and psychologically (Abidde, 2014).

\section{Implication of Boko Haram Insurgency on Agriculture in Nigeria}

Margarita, (2013) explained that more recently, the Boko Haram insurgency in northern Nigeria, ethno-religious conflicts in Central Nigeria, as well as conflicts originated by the Niger Delta militants in response to oil exploitation and environmental degradation in the Niger Delta area. These conflicts have negatively affected the availability and affordability of food items in these areas. Many rural farmers have been displaced while others are restricted from going to their farms because of security checks and the militaristic counter-terrorism approach of the government (Dabugat, 2013).

Merrick and Li (2014) explained that over the past five years, the Nigerian government has kept mostly closed borders with Cameroon, Chad and Niger. This has crippled the agricultural export market in northern states, resulting in the loss of one of Nigeria's largest potential revenue sources. Almost $80 \%$ of Nigeria's northern population are active farmers. But beyond decreased agricultural consumption, higher density insurgence has affected northern locals in other major ways. Millions of livestock have been adversely affected while the region's thriving fishing industry has plummeted. New security measures have been adopted by the state to reduce the impact of Boko Haram's insurgence in the north. An imposed curfew has shortened business hours in some affected areas. Others have increased the use of checkpoints and made everyday movement extremely difficult.

Over a million fishermen in the region have been forced to immigrate with their families to Niger Republic. With insurgents terrorising the citizens in the north, there are fears that even higher levels of the population will take to emigration to ensure their livelihoods and safety. Although there have been no reports of a major attack on the northern state of Kano in recent years, violence in neighbouring states continue to negatively affects its commerce. Closures of northern borders have decreased trade in Kano by half, thus increasing regional food shortages and poverty levels. As such, the National Emergency Management Agency estimates that over 152,000 people have been internally displaced mostly farmers due to attacks on more than 100 communities in north central Nigeria alone, and are unlikely to return to their homes anytime soon (Usman, 2006). Violence in Borno, Yobe and Adamawa states gained momentum with the emergence of President Goodluck Jonathan in May 2011. Over 1.5 million people have fled their homes and at least 13,000 people mostly farmers have died in these states due to violence killing and gun shots (Mustapha, 2015). Maiduguri, the capital of Borno state had witnessed multiples of bombing explosion making the town very insecure for farmers and other businesses. Major markets in the town have become ghosts' area due to insurgency. It is on record that among the six geo-political zones in Nigeria, the North-east and North-west are the poorest zones and these are the zones where Boko Haram originated from and very active (Council on Foreign Relations 2015). 
The bombing of bridges and roads have made land transportation risky and difficult. Movement of goods and man have hence been restricted. Animal husbandry is a common farming business in the north especially with nomadic cattle rearers who have to move from one place to another to feed the cattle. Other farm animals need to be fed to grow well for business and most of the animals' food are obtained from farm products. Insecurity has led to drastic reduction in agricultural output and increase in prices in other parts of the country (Sahara reporters, 2015, Kathleen, 2014). The closing of borders have affected more than just the Nigerian population. Cameroon has been negatively affected by this closure, especially communities closest to the Cameroon-Nigerian border. With no movement between states, there has been a sharp fall in food exports to Nigeria and in commodities such as oil to Cameroon. The border closure has had disastrous consequences for both merchants and residents of Northern Cameroon. Such consequences are seen through these merchants' and residents' dependence on oil and Nigeria as an export community for their produce. With closed borders, the price for commodities has skyrocketed, while transport fares increased by $70 \%$. For these reasons, many of these citizens are unable to export their goods to Nigeria, leaving them to stockpile large quantities of produce. The town of Amchide has been reported to have taken the hardest hit. Amchide has become a ghost town, where the merchants who formerly constituted $90 \%$ of the population have left, giving way to the patrol teams stationed there by Cameroon's military. The increase in violence leaves little hope for those within the region to return home and continue their trades (Merrick and Li, 2014).

Okechukwu (2014) explained that the federal government's effort at augmenting food production at the Chad Basin has come under serious threat from the activities of Boko Haram insurgents in the area. An investigation shows that the several hectares of arable land prepared for the cultivation of rice and other grains in Borno has been abandoned because of the activities of the insurgents. It was gathered that virtually all the farmers involved in rice cultivation and other agriculture-related activities have abandoned the vast expanse of land at the Chad Basin because of the activities of the insurgents. The investigation further showed that the suspension of farming activities in the Chad Basin has resulted in the scarcity of food stuff and an increase in the price of rice (Okechukwu, 2014). All fiscal and domestic policies enacted by the government to boost agriculture especially in the northern states have proved abortive. A sector of the economy which provides employment for more than $70 \%$ of the population cannot be handled with insecurity (Adebayo, 2014, Kathleen, 2014).

Nigerian poultry farmers under the auspices of the Poultry Association of Nigeria (PAN) have also raised concern over the activities of Boko Haram insurgents stating that it is taking a toll on sales of poultry products in Northern Nigeria. The National President of PAN made this clear during the Second Poultry Summit held at the Lagos State Chamber of Commerce and Industry, Alausa. Oduntan (2014) lamented that the activities of the violent sect had resulted in a daily drop in sales due to nonavailability of some raw materials for feeds such as maize and groundnuts which were usually sourced from the affected states. He also revealed that export to neighbouring countries had become impossible. Oduntan (2014) explained that the insurgency had killed retail sales in the North as nightlife has become non-existent. It was during this time that Northerners usually buy eggs in very large quantities from tea sellers. He called on the Federal Government to provide support for the poultry business as it currently cannot satisfy the volume of demand for poultry products in the entire country (Okojie, 2014). The health implication of Boko Haram in the bringing of epidemic in Ideal Dispose People (IDP) areas leading to death of young men and women who could be workers in the agriculture sector.

It is a known fact that a reasonable number of school pupils, youth, women and children have been killed through the indiscriminating gun shots by the terrorist. It is certainly no good news that Boko Haram attacked the College of Education in Yobe leaving over 30 students dead (Ikeji, 2013). It is very pathetic to read that the militants stormed the village of Debiro in Hawal local government area of Borno state and slit the throats of 20 villagers. Debiro is a small village not far from Maiduguri the capital of Borno state (Sahara reporters, 2015). The abattoir in Maiduguri that used to kill hundreds of cows and goats meat suddenly shut itself down due to a bomb explosion (Okojie, 2014). Boko Haram has ruined agricultural business in Nigeria. A business survives only in a peaceful and stable environment. 


\section{Methodology}

Secondary source of data was used for this study. Data were obtained from World Bank showing Nigerian agricultural value added percentage of GDP from 1994 to 2013 a period of twenty (20) years in order to determine the extent of agricultural contributions to Gross Domestic Product (GDP) in Nigeria. It is necessary to use data that had been generated to show the time series effect. Descriptive statistics and T-Test were used in analyzing the data collected. This is with a view to enabling the researchers to obtain the effect of Boko Haram insurgency on the agricultural sector of the Nigerian business environment. The time series method is a set bivariate data of quantitative observations collected over a period. It shows how economic, social, psychological and other factors have changed over time, which could be daily, monthly, quarterly or yearly.

The expression of time series is given by:

$\mathrm{Y}=\mathrm{F}(\mathrm{t})$

Where

$\mathrm{T}$ is the time;

$\mathrm{Y}$, is the variable of interest and;

$\mathrm{F}$, is the Function of the model

\section{Results and Discussion}

This section presents analysis and interprets the data generated for the study. The data was generated from the World Bank for twenty (20) years, (1994-2013).

Table1. Agricultural output (kg) on yearly basis in Nigeria.

\begin{tabular}{|l|l|l|l|}
\hline $\begin{array}{l}\text { YEAR (Period 1, 10 } \\
\text { years 1994-2003 } \\
\text { before the insurgency) }\end{array}$ & $\begin{array}{l}\text { Agricultural output to } \\
\text { Nigeria GDP }\end{array}$ & $\begin{array}{l}\text { YEAR ( Period 2, 10 } \\
\text { years 2004-2013 } \\
\text { during the insurgency) }\end{array}$ & $\begin{array}{l}\text { Agricultural output to } \\
\text { Nigeria GDP }\end{array}$ \\
\hline 1994 & 38.8108824 & 2004 & 34.21028658 \\
\hline 1995 & 32.06099353 & 2005 & 32.75542177 \\
\hline 1996 & 31.13372236 & 2006 & 31.9987955 \\
\hline 1997 & 34.03135991 & 2007 & 32.71417898 \\
\hline 1998 & 39.0478495 & 2008 & 32.85021918 \\
\hline 1999 & 35.30644453 & 2009 & 37.05016484 \\
\hline 2000 & 26.03397777 & 2010 & 23.89370408 \\
\hline 2001 & 33.7537884 & 2011 & 22.28919858 \\
\hline 2002 & 48.56594018 & 2012 & 22.05428761 \\
\hline 2003 & 42.70726998 & 2013 & 20.99639753 \\
\hline
\end{tabular}

Source: World Bank 2015 


\section{Analysis of the period of 1994 to 2013}

T-Test was conducted to show an Appraisal of the Effect of Boko Haram insurgency on the Agriculture Sector of Nigerian Business Environment: Output from 1994 to 2003 and output from 2004 to 2013.

Table 2: Group statistic of Agricultural output in Nigeria.

Group Statistics

\begin{tabular}{|ll|l|l|l|l|}
\hline & Group Variable & N & Mean & Std. Deviation & $\begin{array}{l}\text { Std. Error } \\
\text { Mean }\end{array}$ \\
\hline \multirow{2}{*}{ Output } & Output (1994-2003) & 10 & 36.1452229 & 6.39261667 & 2.02152289 \\
& Output (2004-2013) & 10 & 29.0812655 & 6.02781669 & 1.90616301 \\
\hline
\end{tabular}

The table above shows the evaluation of the descriptive statistics i.e. the mean scores of the two groups concerned, the output from 1994 to 2003 and the output from 2004 to 2013. It was noted from the table that a difference (7.06395739) existed between two groups, as the output from 1994 to 2003 had a mean score of 36.1452229 while the output from 2004 to 2013 had a reduced mean score of 29.0812655. Furthermore, as the numbers of years for 1994 to 2003 output were ten (10) years, while the numbers of years for 2004 to 2013 output were ten (10) years, the observed difference of 7.06395739 in their mean of their total performance scores could be as a result of the difference in reduction in the output in 2004 to 2013, which could not be avoided due to insecurity. This implies that the output was affected between 2004 to 2013 compared with 1994 to 2003 . The two groups are really different. The significance of the groups' is tested and presented in the table below.

Table 3: T- Test output performance

\begin{tabular}{|c|c|c|c|c|c|c|c|}
\hline & \multicolumn{7}{|c|}{ T-Test for Equality of Means } \\
\hline & \multirow[b]{2}{*}{$\mathrm{t}$} & \multirow[b]{2}{*}{ Df } & \multirow{2}{*}{$\begin{array}{l}\text { Sig. (2- } \\
\text { tailed) }\end{array}$} & \multirow{2}{*}{$\begin{array}{l}\text { Mean } \\
\text { Difference }\end{array}$} & \multirow{2}{*}{$\begin{array}{l}\text { Std. Error } \\
\text { Difference }\end{array}$} & \multicolumn{2}{|c|}{$\begin{array}{l}95 \% \text { Confidence } \\
\text { Interval of the } \\
\text { Difference }\end{array}$} \\
\hline & & & & & & Lower & Upper \\
\hline $\begin{array}{l}\text { Output } \\
\text { Performance }\end{array}$ & 2.542 & 17.938 & 0.020 & 7.06395739 & 2.77849099 & 1.22512277 & $\begin{array}{l}12.902 \\
79201\end{array}$ \\
\hline
\end{tabular}

T-test Calculated $($ Statistic $)=2.542$, Degree of freedom $=17.938$, Level of significance $=0.05$, Returned p-value $=0.020$

\section{Interpretation}

The t-test statistics was calculated as 2.542, at 5 percent level of significance under 17.938 degrees of freedom, the output $\mathrm{p}$-value of 0.020 was found less than the accdpted level of significance $\mathrm{p}<0.05$. Thus the null hypothesis was rejected. Hence, $(\mathrm{Hi})$ Boko Haram insurgency affects the Agricultural Sector of Nigerian Business Environment: Output from 1994 to 2003 and Output from 2004 to 2013. This implies that between the periods of 2004 to 2013 Boko Haram insurgency had negative impact on Nigerian Agricultural Sector Output.

\section{Conclusion and Recommendations}

Boko Haram insurgency in Nigeria and some of its neighbouring countries have adverse consequences on the economy. The agricultural business environment has been affected. This has been evidenced by the reduction of valued added to the economy between the periods under investigation. Evidence has also shown that the conflict or terrorist activities have disrupted the agricultural output and economy 
of the people living in the Northern states as most inhabitants and farmers have migrated to a better and safer place. The insurgency has also affected the exportation of agricultural inputs needed for conversion and transformation in other industries that rely on inputs like rubber, cocoa, fertilizer, etc.

In addition to revamping and controlling the country's agricultural business sector as it was in the 1960s, the government should take drastic action to stop this unbearable act of Boko Haram in addition to its other agricultural policies. Also, State governments should engage in specific agricultural activities on the basis of the principles of comparative advantage. This is because less dependency on the Northern states for agricultural products or inputs would likely reduce the effect of this insurgency on food prices in other states.

The neglect of agriculture which was an important source of revenue most especially in the area of foreign exchange earnings for the government has become reduced drastically due to over reliance on oil and corruption in the country. It is recommended that government should encourage youths to imbibe farming as part of Nigerian culture by providing basic amenities and social infrastructures in rural areas.

\section{References}

Abayomi, F. (2006). An overview of Nigerian agricultural sectors. Journal of Agricultural Economics, $8,(3): 7-16$.

Abdullahi, A. (2003). Employment creation and opportunities in the agro-allied sub-sector: The case of cassava production. CBN Bullion Publication, 27(4): 10

Abidde, S. (2014, February 1). The impact of Boko Haram on Nigeria. The Punch Newspaper, p. 18

Adebayo, A. (2014). Implications of 'Boko Haram' terrorism on national development in Nigeria: A Critical Review. Mediterranean Journal of Social Sciences MCSER Publishing, Rome-Italy, 5(16):23-95.

Akinwumi, A. (2014, August 8). Agriculture is the future of Nigeria. The Financial Times. Retrieved from http://www.financialtimes.com

Akinwumi, A. (2015 July 18). Oil vs Agriculture: walking a tight rope ahead. Saturday Monitor. Retrieved from http://www.monitor.co.ug.

Central Bank of Nigeria (1995). Annual Report and Statement of Account, Lagos, Nigeria.

Central Bank of Nigeria (2007). Annual Report and Statement of Account, Lagos, Nigeria.

Christopher, E. (2010). "Agricultural financing policies and rural development in Nigeria", Paper presented at the 84th annual conference of the agricultural economics society, Edinburgh.

Dabugat, K. K. (2013). Special report: Food security challenges in West Africa: A focus on agriculture. West Africa Insight, October, 2013 Agriculture.

Daniel, S. U. and Ihechituru, O. K. (2012). Effect of agricultural reforms on the agricultural sector in Nigeria. Journal of Africa Studies and Development vol.4 (2), pp.51-59

Evbuomwan, G. O. et al (2003). Agricultural development: Issues of sustainability, contemporary economic policy issues in Nigeria. Abuja: Research Department, Central Bank of Nigeria. pp: $185-221$.

Francis. N. F. and David. A. K. (2012). The challenges of agriculture and rural development in Africa: The Case of Nigeria. International Journal of Academic Research in Progressive Education and Development. 1(3), 2226-6348.

Igboeli, G. (2000). Development of agriculture in Nigeria. In Nworgu F. C. (Ed) Prospects and pitfalls of agricultural production in Nigeria. Federal College of Animal Health and Production Technology, Institute of Agricultural Research and Training, Ibadan, Nigeria.

Innocent, E.O. and Ibietan, J. (2012). The cost of Boko Haram activities in Nigeria. Arabian Journal of Business and Management Review (OMAN Chapter) 2(2)12-20.

Iwuchukwu, J. C. and Igbokwe, E.M. (2012). Lesson from agricultural policies and programme in Nigeria. Journal of Law, Policy and Globalisation. Vol. 5. 11-21 
Lawal, W. A. (2011). An analysis of government spending on agricultural sector and it contribution to GDP in Nigeria. International Journal of Business and Social Science Vol. No 20, 244-250 www.jibssnet.com

Mabuza, M. L., Tae, M. and Endo, M. (2008). Impact of food aid on small wilder. agricultural development in Swaziland. African Journal of Agriculture, 8 (2): 151-169.

Margarita, F. (2013). Conflicts, rural development and food security in West Africa. ESA working paper 04-02, P 2-19

Merrick, M. and Li, Q. (2014). The effects of Boko Haram insurgency on business and trade. Http://Africabordermonitor.Com/Media.Php

Mustapha, M. (2015). Boko Haram insurgency gnawing at Nigeria's food supply. Bloomberg business. Retrieved from http://www.bloomberg.com

Nworgu, F. C. (2006). Prospects and pitfalls of agricultural production in Nigeria. Federal College of Animal Health and Production Technology, Institute of Agricultural Research and Training, Ibadan, Nigeria.

Nseabasi, S. A. (2012). Rural development in Nigeria: A review of Pre and Post - independence practice. Journal of sociological Research Vol.3 No 2 pp.1948 -5468.

Oduntan, A. (2014). Poultry farmers concerned over Boko Haram insurgence. Http://Agronigeria.Com.Ng/2014/06/10.

Okechukwu, N. and Soriwei, F. (2013). Boko Haram: Multi-Billion naira irrigation project under threat. Http://www.Punchng.Com/News

Okojie, G. (2014, 15 May). Boko Haram insurgency ruined farming in Nigeria. Leadership. Retrieved from Http://Leadership.Ng/News/370912/.

Okogun, O. A. and Abang, S. I. (2013). Poverty alleviation information and communications technology: A case study of Nigeria. International Journal of Multidisciplinary Science and Engineering Vol. 4 , No. 7 August 2013, P 20-24

Olaide, I. A. (2013). Boko Haram insurgency in Nigeria: Its implication and way forward towards avoidance of future insurgency. International Journal of Scientific and Research Publication Vol. 3 P 1-7, ISSN2250-3153.

Olayide, S. (1981). Elements of Rural Economics. Ibadan: University Press, Nigeria

Olugboyega, O. and Kolawole, O. (2012). Policies and program for poverty reduction in rural Nigeria." An interim research report submitted to the African Economic Research Consortium (AERC), Nairobi, for the second phase of collaborative poverty research project.

Olukoya, O. N. (2007). The agricultural sector and Nigeria's development: Comparative perspectives from the Brazilian agro - industrial economy, 1960 - 1995.pp.184 - 194.

Shiru, J. J. (2008). "Agricultural mechanisation for rural development". Bida Journal of Management and Technology, 1: 45-57.

Towobola, W. L., Luqman, R., Kolade, T. T., Ogunwale, A. B. and Olakojo, S. A. (2014), Entrepreneurship: A vehicle for sustainable food production in Nigeria. Journal of Poverty, Investment and Development. Vol. 5 pp. 23 - 24

Titilola, S. T. (2008). "Environment and sustainable agricultural development in Nigeria". In Adedotun O. Phillips and Eddy C. Ndekwu (Eds), Structural Adjustment Program in a Developing Economy: The case of Nigeria, Ibadan: NISER

Ugwu, D. and Kani, I. (2012). Effects of agricultural reforms on the agricultural sector in Nigeria. Journal of African Studies and Development Vol. 4(2): 51-59.

Ukpong, I. I. and Iniodu, P. U. (1995). The impact of the structural adjustment programme on Nigerian agriculture. Nigeria Journal of Economic and Social Studies, 36 (2), 23-32.

Umebali, E. E. and Akubuilo, J. C. (2006). Readings in cooperative economics and management. Lagos: Computer Edge Publishers.

Usman, N. E. (2006). "Agriculture: vital to Nigerian economic development." Paper presented at the forum of economic stakeholders on "Growing the Nigeria economy". This Day Newspaper, July 25, 2006.

World Bank (2015). Agriculture, value added (\% of GDP). Retrieved from http www.data.world.org, Accessed: June 18, 2015. 